\title{
Geochemical Evaluation of Campanian Sirte Shale Source Rock, Arshad Area, Sirt Basin, Libya
}

\author{
KhaledK. ${ }^{1}$,Darwish M. ${ }^{2}$, Abu Khadra A. ${ }^{2}$ and Burki ${ }^{3}$. \\ ${ }^{I}$ Geology Department, Helwan University, Cairo-Egypt. \\ ${ }^{2}$ Geology Department, Cairo University, Cairo-Egypt. \\ ${ }^{3}$ Geology Department, Cairo University, Cairo-Egypt.\& Sirte Oil Co., Libya
}

\begin{abstract}
The present geochemical study deals with evaluation of Sirte Shale (Campanian) source rock in Arshad area which is located in the central Sirt Basin in north central Libya. Sirte Formation is composed mainly of shale, sandy shale, being partially sandy and calcareous facies indicating presence of possible source rocks. It contains enough amount of organic matter (>0.5 wt. \%) to generate and expel hydrocarbons under suitable thermal maturity level in the area. The recorded kerogens belong to types III and IV. The pyrolysis results indicate deficient of hydrogen content and poor potential source rocks in all samples. The HI values of the analyzed samples prove predominance of type III (gas-prone) and type IV (non-hydrocarbon potential) kerogens. In general, pyrolysis results and derived parameters indicate poor generating potential for the Sirte Formation (Campanian) in the area and mature kerogen in the oil-window zone. The thermal burial history curves of selected wells in Arshad area indicate that Sirte Shale had been buried in the top peak oil generation or oil window (Late maturity, Ro: 0.9-1.35\%) since 4 to 13.5 M. Y. ago at depth range 9100'-9600'. Time of hydrocarbon expulsion has started in the area since 15 M. Y. nearly during the Middle Miocene time (Serravallian age).

In Sirt Basin, oil has migrated from the Campanian Sirte Shale source rock which has reached the oil-window at western flank of the South Ajdabiya Trough to the Mesozoic and Paleozoic reservoirs in Zaltan Platform and to the Upper Cretaceous Arshad sandstone reservoir in Arshad oil field as well. The migrated hydrocarbons most likely are entrapped in the structural closures of the different structural traps (folds and fault-blocks) in Zaltan Platform. Likewise, westward up-dip direction of gas migration took place from the Campanian Sirte Shale source rock as buried in the gas-window in the deep Wadayet (NW Ajdabiya Trough) to the Mesozoic and Paleozoic reservoirs in Zaltan Platform
\end{abstract}

Keywords: Geochemical evaluation, source rock, Sirte Shale, Arshad oil field, Sirt Basin, Libya.

\section{Introduction}

Eighty percent of exploration drilling in the Sirt Basin has been on the platform areas at depths less than $3000 \mathrm{~m}$ (Hallett and El Ghoul 1996). Most hydrocarbons reservoirs consist of pre-Tertiary dominated clastic reservoirs and Tertiary dominated carbonate reservoirs. Oil accumulations have been found from depths of $700 \mathrm{~m}$ to as deep as $4000 \mathrm{~m}$. The oils are generally sweet, with sulphur content between 0.15 and $0.66 \%$, and with relatively little gas. Oil gravity is usually within the range $44^{\circ}$ to $32^{\circ} \mathrm{API}$, and within a temperature range of $52^{\circ} \mathrm{C}$ to as high as $143^{\circ} \mathrm{C}$.

In Sirt Basin, the Upper Cretaceous principal source rock with different thicknesses are deep marine shales accumulated in troughs whereas shallow marine carbonates and clasticsdeposited in platforms represent the hydrocarbon reservoirs. The Upper Cretaceous organic-rich shale was deposited first, after which continued subsidence led to the gradual on-lap of the platforms during the Late Cretaceous (Hallett, 2002).

\section{Objective of the study}

The aim of the study is to define and characterize the source rocks of the penetrated sediments in the study area and to delineate the main zones of oil and gas generation if present. These aims will be achieved by applying geochemical techniques as well as palynofacies and thermal maturity in order to assess the Upper Cretaceous source rocks of the Arshad area. Indeed, this work provides comprehensive picture of the petroleum system in the area which could improve help in further exploration and new prospects in Arshad area.

\section{The used geochemical data}

Geological and geochemical data from three wells (A5, A3, and A8, Fig. 1)in the Arshad area are used. The geochemical data was generated from a series of conventional cores and ditch cutting shale samples and crude oil samples from the source rocks Sirte Formation within the study area. The geochemical results carried out in Geological Laboratory of Sirte Oil Company. The samples for source rock analysis for organic richness, hydrocarbon potential and kerogen types (Rock-Eval) were collected from wells in the study area. Pyrolysis 
results of 51 shale samples of Sirte Formation and microscopic maceral and palynomprphs analysis of some samples were considered. Composition of organic matter, palynofacies, paleo-environment and preservation of source rocks were obtained from examination of kerogen slides under transmitted light. The palynological analysis has been processed in Geological Laboratories of Sirte Oil Company and Arabian Gulf Oil Company during the study period. The samples have been investigated by using Axioplan 2 Image Microscope.

\section{Location of the studyarea}

The Arshad area lies on the Concession 6 in the Zaltan Platform within the Sirt Basin, south of Attahaddy gas field, northeast of Lehib oil field and north of the Zelten oil field, approximately between latitudes $29^{\circ} 10^{\prime} \mathrm{N}-29^{\circ} 32^{\prime} \mathrm{N}$ and longitudes $19^{\circ} 30^{\prime} \mathrm{E}-20^{\circ} 00^{\prime} \mathrm{E}$ (Fig. 1).

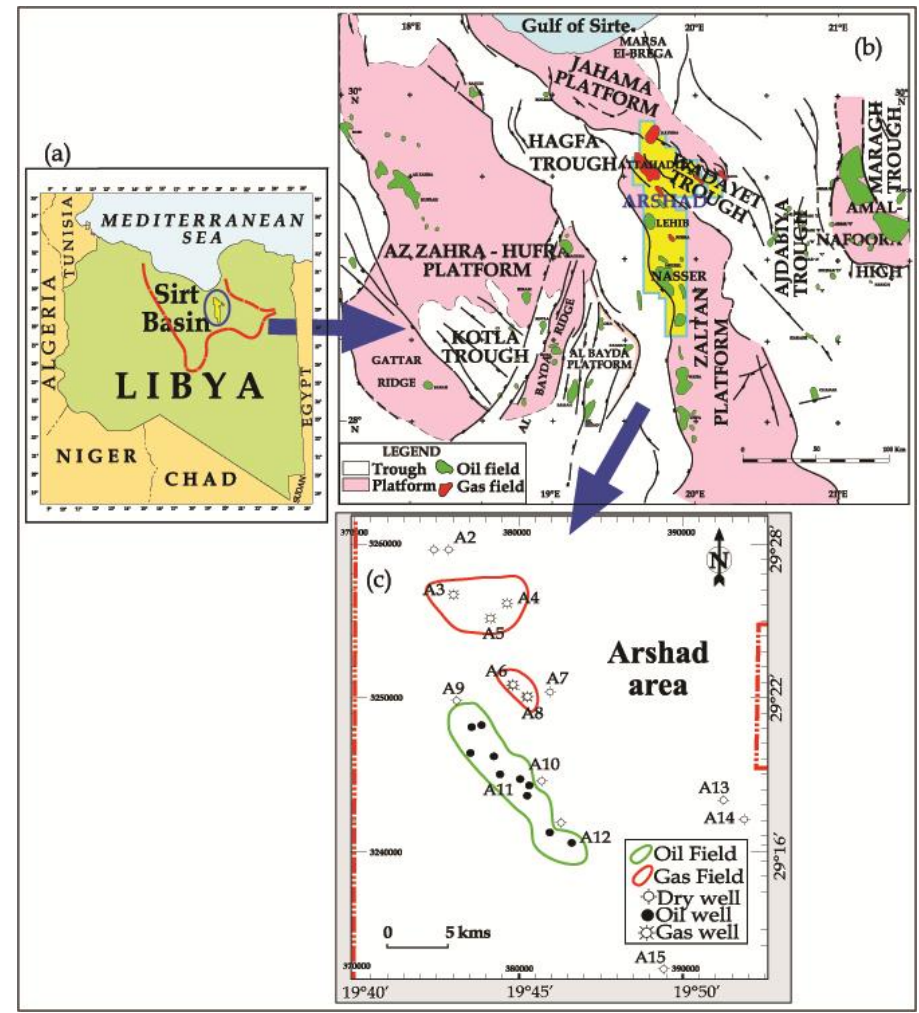

Fig. 1.(a) Location Map of Sirt Basin in Libya. (b) Study area within Concession 6 (yellow) and (c) Arshad area includes studied wells; A5, A3, A8, A10 and 3M10-6.

\section{Evaluation Of Sirte Shale Source Rock}

In general, the source rock evaluation is based on four parameters, the organic richness; type of organic matter (kerogen); level of thermal maturation, and source potential and expulsion efficiency. In this study, the Sirte Shale source rock is evaluated as adequate potential source rock which can generate hydrocarbons in Sirt Basin and Zaltan platform in relative to the trough areas in the basin.

The sedimentary succession in Arshad area includes several shale intervals. These shales are within formations: Sirte (Campanian), Hagfa (Early Paleocene), Kheir (Late Paleocene-Early Eocene) and Diba and Marada (Miocene) (Fig. 2). Among these shale intervals the Sirte Shale is considered the promising source rock since it is the oldest thick syn-rift shales deposited during the Late Cretaceous time on the entire area of Sirt Basin; it is buried in deep depths (> 2900m) in the troughs and had been affected by many tectonic phases. 


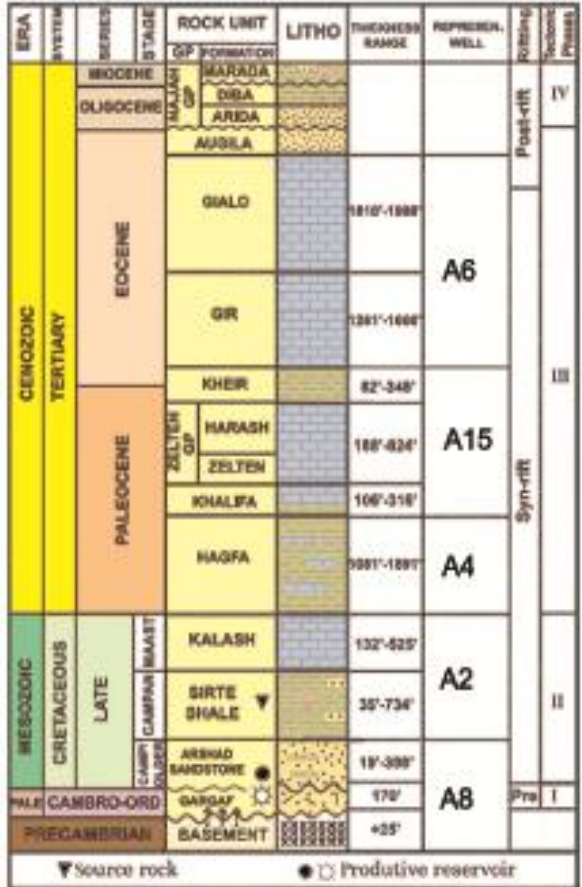

Fig. 2.Generalized stratigraphic sequence of central Sirt Basin, Libya.

\section{Sirte Formation-Late Cretaceous}

In general, the drilled Sirte Formation section is dominantly a shale sequence alternating with thin limestone interbeds. It is widely distributed in the troughs of the Sirt Basin and the studied area as well. It attains 570' thick at O2-59 well (Barr and Weegar, 1972). The lithofacies map of Sirte Formation shows that it is composed mainly of shale, sandy shale and limy shale facies indicating presence of possible source rocks (Fig. 3). Meanwhile, the shale percent decreases markedly to the northeast direction where the facies change to shaley-sand and calcareous facies. Also at the southwestern part the sandy-limestone and shaley-limestone facies are dominant. Hence, it is expected to find a source rock facies along the central northwest-southeast trending belt where most of the discoveries are found (Fig. 3).

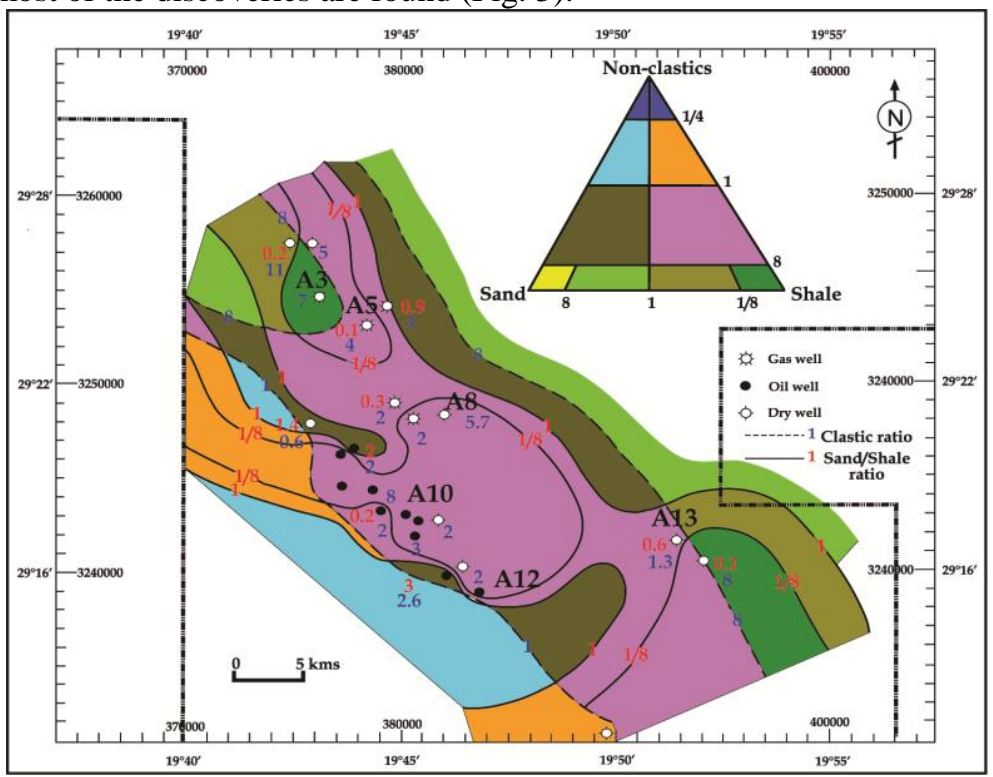

Fig. 3:Lithofacies map of Sirte Formation in Arshad area.

Generally, Sirte Formation is conformably overlain by Kalash Limestone. Its color from dark gray to dark brown and sub-fissile to splintery and waxy in character with thin argillaceous limestone stringers which often contain high-pressure gas. These shales contain abundant planktonic foraminifera, which indicate a Campanian age (Barr and Weegar, 1972) being deposited in marine conditions (Clifford, 1986; Lewis, 1990). 
Palenologically, Sirte Shale in Arshad wells is of Campanian age and was deposited under marginal marine environment. Consequently, Sirte Formation is considered the principal source rock in trough areas in the Sirt Basin for most of hydrocarbons due to the presence of the organic-rich components over 4921' thick which is usually bituminous. The kerogen content of Sirte Formation is attested to deposition under oxygen depleted marine reducing conditions.

The drilled section of Sirte Formation is usually present in Arshad area at depths 10796' with maximum thickness of 734' at A2 well (Fig. 4). Subordinate dolomite layers are observed in the lower part of the Sirte Formation in some wells, A2, A14, A13, A7, and A6, being absent at scattered places over the crest of the platform. Also, they are absent on the high block in wells A10, A11 and A15 due to the structural complexity (Fig. 4).

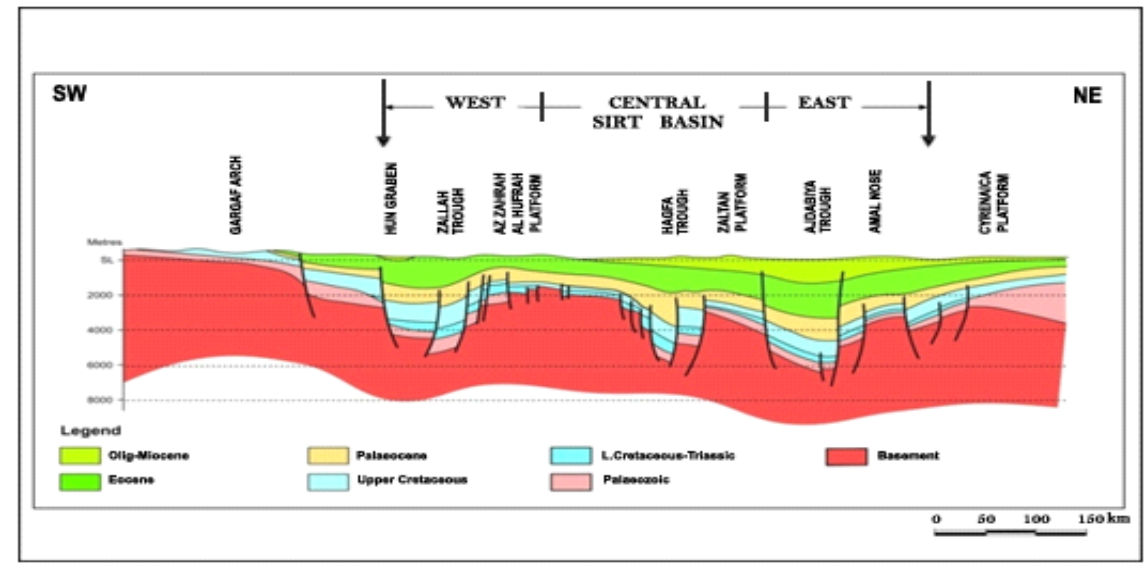

Fig. 4. SW-NE structural cross-section showing the major platforms and troughs across Sirt Basin based on wells and seismic data. (From Hallett, 2002 and modified by present study).

\section{Organic matter abundance of Sirte Shale}

The geochemical analysis of the TOC of samples from Sirte Shale in the studied three wells (A5, A3, and A8) indicates a fair to good source rock since the values ranges from 0.25 to $1.04 \mathrm{wt} . \%$ and the average values is $0.58 \mathrm{wt} . \%$ (Table 1). The TOC rich depth intervals are that from 10620'-10890' in well A5 (TOC value ranges from 0.7 to 1.04 wt. \%) and depth interval from 10920'-10990' in well A3 (TOC value equals 1.01 wt. $\%)$. In the third well A8 the Sirte Shale shows low TOC values not more than the cutoff value $(0.5$ wt. \%) required to generate hydrocarbons. In general, most of the TOC values of the analyzed samples are higher than the cutoff TOC value ( 0.5 wt. \%) (Figs. 5 and 6 ). The average values of the analyzed samples of the three wells are $0.65,0.56$, and $0.51 \mathrm{wt} . \%$, respectively. The average of the TOC results of all samples is $0.58 \mathrm{wt}$. \% (Table 1). This indicates that Sirte Shale contains enough amount of organic matter to generate and expel hydrocarbons under the suitable thermal maturity level in the area. Consequently, the generation potential of Sirte Shale is considered and evaluated in the present study.

Table 1. Average values of the Rock-Eval pyrolysis, TOC and Ro data of Sirte Shale in some wells, Arshad area, Zaltan Platform, Sirt Basin.

\begin{tabular}{|c|c|c|c|c|c|c|c|c|}
\hline Well Name & TOC,wt.,\% & $\begin{array}{c}\text { S2, } \mathrm{mg} \\
\mathrm{HC/g} \\
\text { rock }\end{array}$ & $\begin{array}{c}\text { GP: } \\
\text { (S1+S2), } \\
\text { mg HC/g } \\
\text { rock }\end{array}$ & PI: S1/(S1+S2) & S2/S3 & $\begin{array}{c}\text { Tmax, } \\
{ }^{\circ} \mathrm{C}\end{array}$ & $\begin{array}{c}\mathbf{H I ,} \\
\mathrm{mg} \\
\mathrm{HC} / \mathrm{g} \\
\text { TOC }\end{array}$ & Ro, \% \\
\hline A5 & 0.65 & 0.27 & 0.48 & 0.43 & 1.04 & 390 & 42 & 1.35 \\
\hline A3 & 0.56 & 0.15 & 0.28 & 0.48 & 0.47 & 384 & 24 & 1.36 \\
\hline A8 & 0.51 & 0.12 & 0.18 & 0.30 & 0.37 & 411 & 25 & 1.4 \\
\hline \hline Average & $\mathbf{0 . 5 8}$ & $\mathbf{0 . 1 7}$ & $\mathbf{0 . 2 9}$ & $\mathbf{0 . 4 0}$ & $\mathbf{0 . 5 7}$ & $\mathbf{3 9 5}$ & $\mathbf{3 0}$ & $\mathbf{1 . 3 7}$ \\
\hline
\end{tabular}




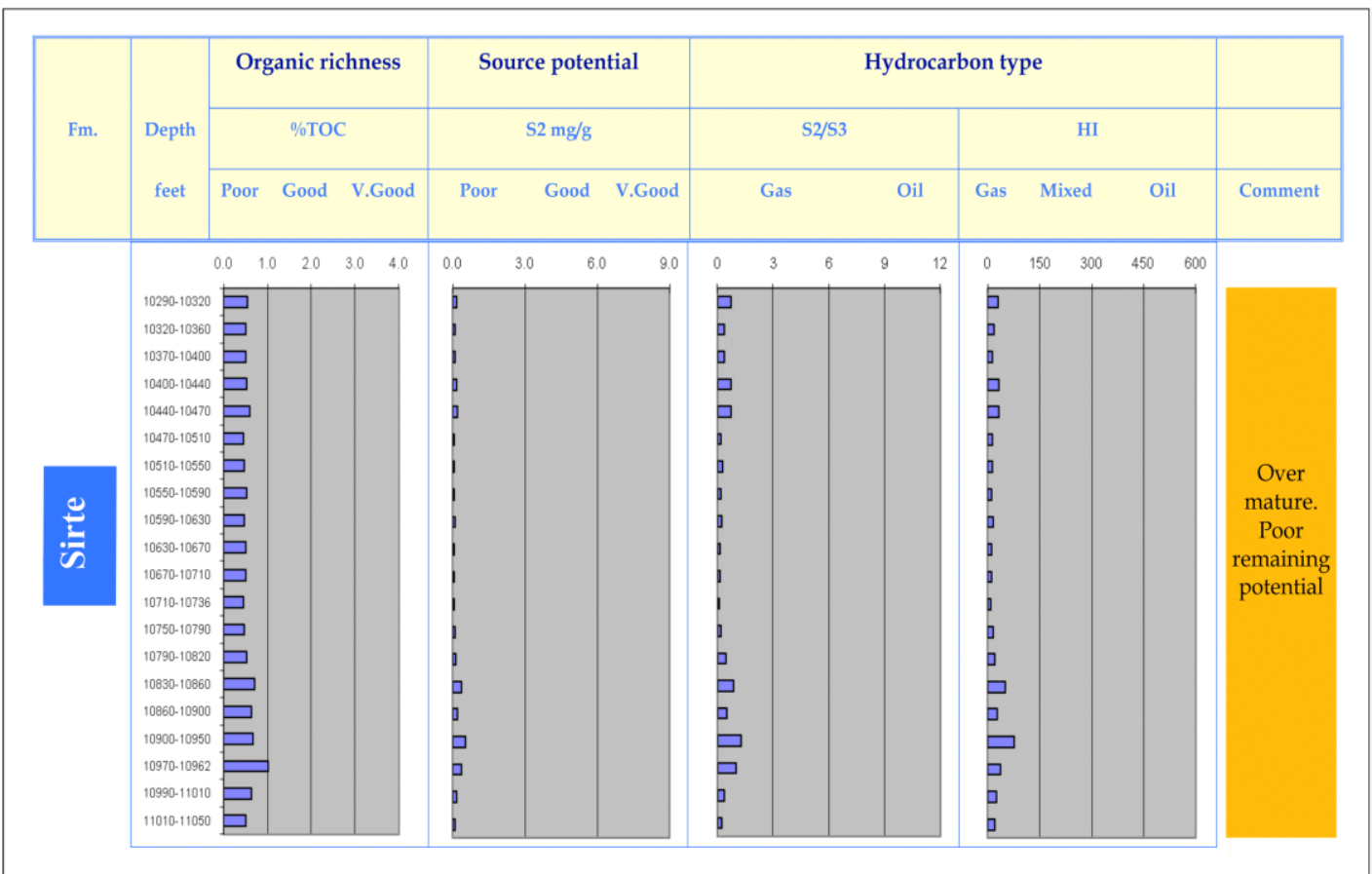

Fig. 5.Results of pyrolysis data of well A3, Arshad area, Zaltan Platform, Sirt Basin, Libya.

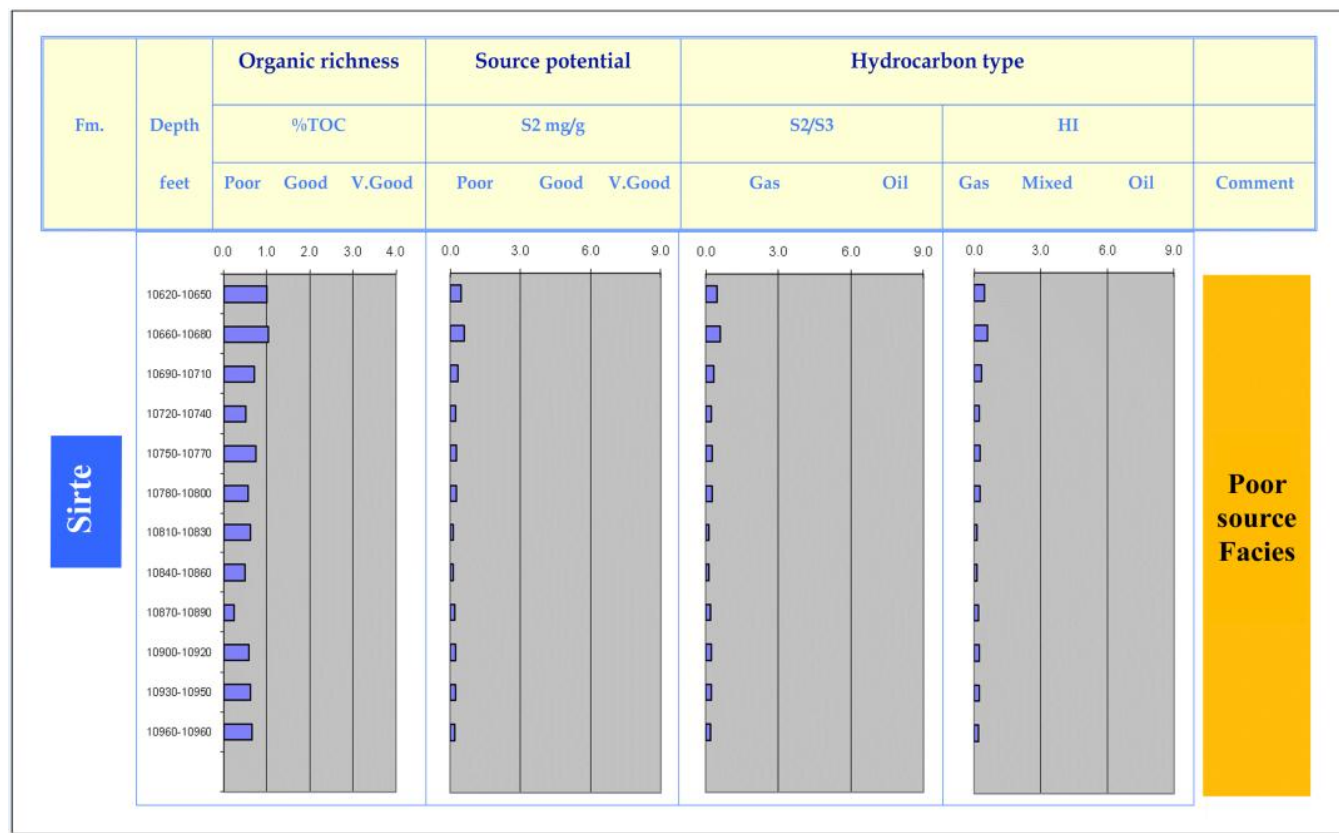

Fig. 6.Results of pyrolysis data of well A5, Arshad area, Zaltan Platform, Sirt Basin, Libya.

\section{Type of organic matter in Sirte Shale}

Type of organic matter in Sirte Shale is determined by microscopic examination of the isolated kerogen residue and maceral analysis of the different organic constituents. In addition, results of Rock-eval Pyrolysis technique are considered to construct the modified Van Krevelen diagram to allocate the plots of the analyzed samples.

The microscopic examination of kerogenmacerals reveals the percentage of kerogenconstituentssapropel, vitrinite and inertinite. Also, Figure 7A shows masses of allochtonous detrital carbonized humic materials of inertinite extracted from the Sirte Shale of well A3. The black and relative dark brown colors indicate melanization which results in the conversion of the fungal material into material equivalent to the inertinitemaceral. These inertinite masses have no hydrocarbon potential due to the complete loss of their hydrogen content. 
Plotting of percentages of the different macerals (liptinite, vitrinite and inertinite) and phytoclasts (amorphous, palynomorphs) of these kerogens indicates that these kerogen materials consist mainly of the degraded amorphous organic matter with less amounts of the exinite and woody materials and they belong to the distal oxic shelf marine palynomorphs (Fig. 7B).

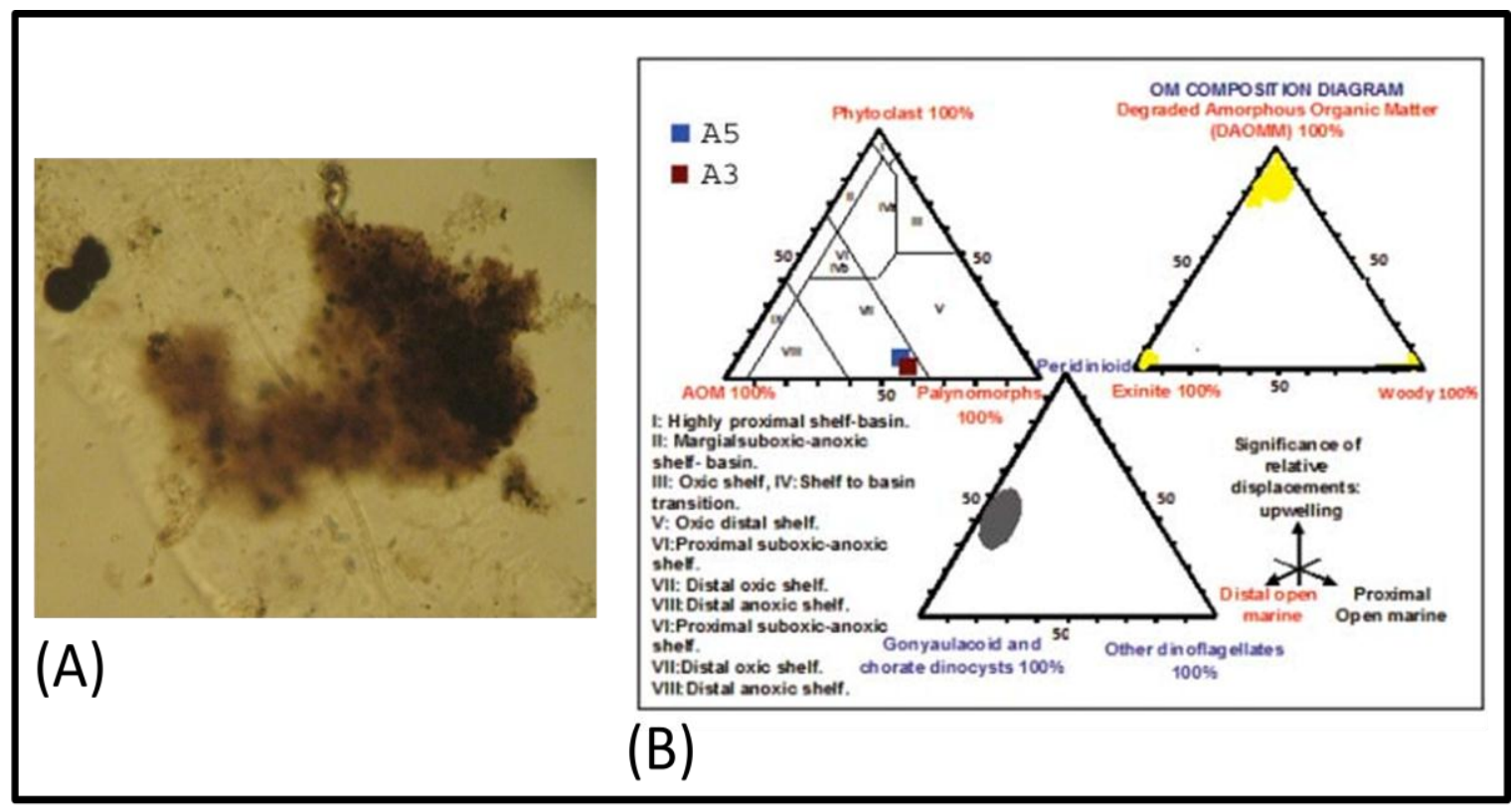

Fig. 7:A. Poorly preserved inertinitemaceral of kerogen separated from Sirte Shale, A3 well (under transmitted light). (B). Marine facies field diagram, organic matter (OM) composition diagram and Microfossil assemblage diagram of the Sirte Shale, Arshad area, Zaltan Platform, Sirt Basin, Libya.

The pyrolysis $\mathrm{HI}$ values (mg HC/g TOC) of kerogens of analyzed samples from wells (A5, A3 and A8) range from 9 to $76 \mathrm{mg} \mathrm{HC/g}$ TOC and the average values are 42, 24 and $25 \mathrm{mg} \mathrm{HC} / \mathrm{g} \mathrm{TOC}$ respectively. These values indicate deficient of hydrogen content and poor potential source rocks in all samples (Figs. 5-6 and Table 1). Waples, (1985) differentiated kerogens into three types based on their hydrogen index values. Accordingly, the $\mathrm{HI}$ values ( $<150 \mathrm{mg} \mathrm{HC/g} \mathrm{TOC}$, average $30 \mathrm{mg} \mathrm{HC/g} \mathrm{TOC}$ ) of the analyzed samples prove predominance of type III (gas-prone) and type IV (non-hydrocarbon potential) kerogens. Also, the OI values of the analyzed rock samples range from 24 to $116 \mathrm{mg} \mathrm{CO} / \mathrm{g}$ TOC indicating very low oxygen content of kerogens. Consequently, based on pyrolysis results of these samples, hydrogen index HI (mg HC/g TOC) and oxygen index OI (mg CO2/g TOC) of kerogens plotted on the modified van Krevelen diagram, the analyzed samples from wells A5, A3 and A8 are also located in the zone of gas-prone mature type III (and type IV) kerogen (Fig. 8). It is worth to mention that, it is difficult to distinguish between the different types of kerogen of very low hydrogen and oxygen contents. This is shown in the composite van-krevelen diagram of all samples from the three wells where the pathways of the three kerogen types are very close to each other or merged in the postmature zone (Fig. 8). Therefore, it is important and necessary to get help of the visual microscopic study of kerogenmacerals in order to determine the dominant kerogen type of the studied samples. 


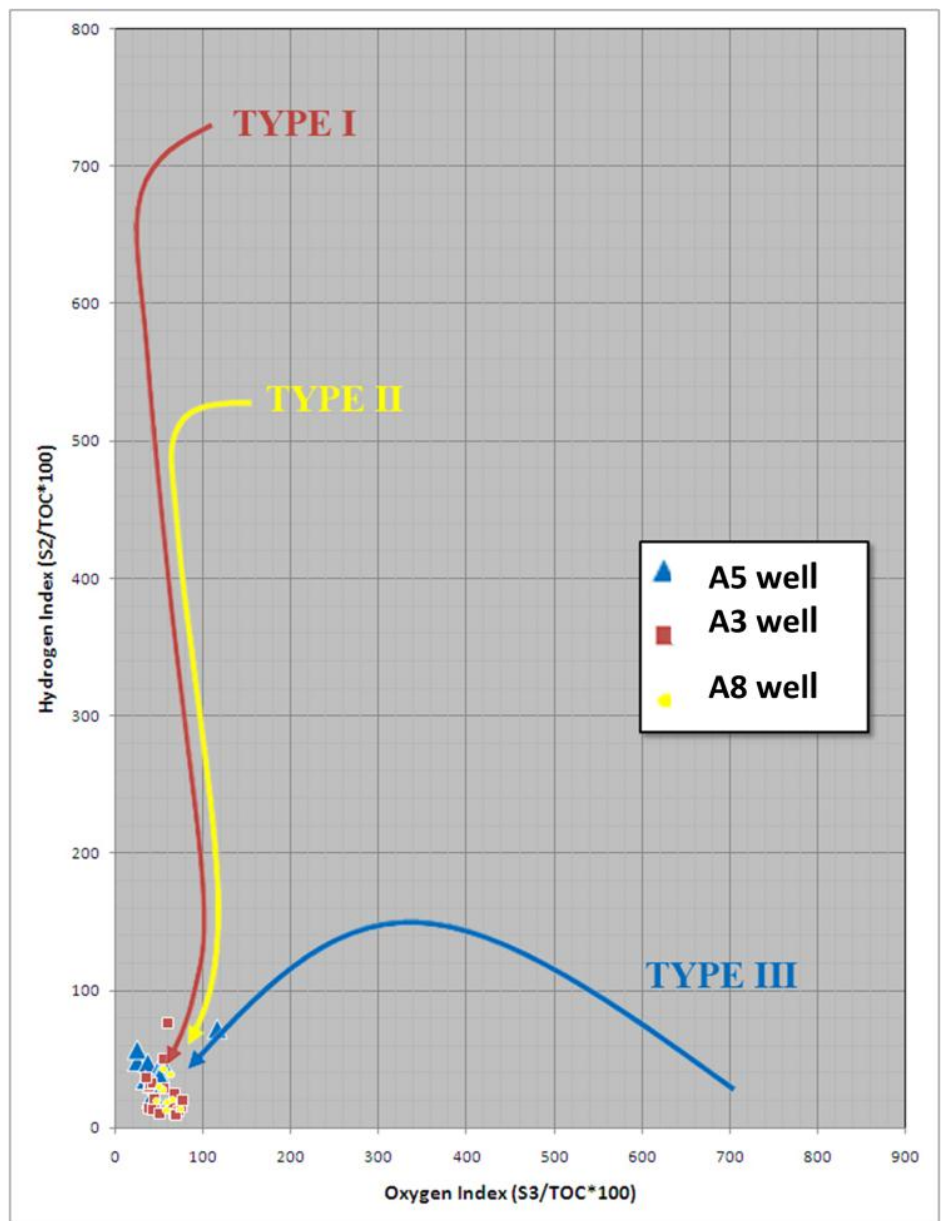

Fig. 8.Composite modified Van Krevelen diagram of Sirte Shale, wells: A5 and A3, and A8, Arshad area, Zaltan Platform, Sirt Basin, Libya.

\section{Source Potential (Generating Capability)}

The source generating potential(capability) of the Sirte Formation in wells A5, A3, and A8 is indicated by the pyrolysis-derived S2 peak (hydrocarbon cracked from kerogen, mg HC/g rock) results (Table 1). The average value of S2 values of the analyzed samples in the three wells measures $0.17 \mathrm{mg} \mathrm{HC} / \mathrm{g}$ rock reflecting very poorgenerating potential source rocks (Figs. 5, 6 \&9). In general, a direct relationship between S2 and TOC values are recorded (Fig. 10). The average values of the analyzed samples in wells: A5, A3, and A8 are 0.27, 0.15 and $0.12 \mathrm{mg} \mathrm{HC} / \mathrm{g}$ rock, respectively (Table 1). This confirms the poor generating hydrocarbon potential of the Sirte Shale in the area.

Also, plotting of values of pyrolysis-derived S1 peak (free hydrocarbon content of the pyrolyzed samples, $\mathrm{mg} \mathrm{HC/g}$ rock) versus TOC (wt. \%) shows a normal expected direct relationship indicating indigenous hydrocarbons of all analyzed samples of the three wells (Fig. 11).

The total genetic potential $(\mathrm{GP}=\mathrm{S} 1+\mathrm{S} 2)$ of these samples is very low as it ranges from 0.23 to 1.09 (average 0.48 ) $\mathrm{mg} \mathrm{HC} / \mathrm{g}$ rock in well $\mathrm{A} 5$, from 0.08 to 0.99 (average 0.28 ) $\mathrm{mg} \mathrm{HC} / \mathrm{g}$ rock in well A3, and from 0.05 to 0.43 (average 0.18 ) $\mathrm{mg} \mathrm{HC} / \mathrm{g}$ rock in well $\mathrm{A} 8$. These values (average $0.29 \mathrm{mg} \mathrm{HC} / \mathrm{g}$ rock) indicate a poor source rock.

The production index $(\mathrm{PI}=\mathrm{S} 1 / \mathrm{S} 1+\mathrm{S} 2)$, or transformation ratio $(\mathrm{TR})$, ranges from 0.36 to 0.50 (average 0.43 ) in well $\mathrm{A} 5$, from 0.36 to 0.57 (average 0.48 ) in well $\mathrm{A} 3$, and from 0.11 to 0.60 (average 0.30 ) $\mathrm{mg} \mathrm{HC/g}$ rock in well A8 (Table 1). These values (average 0.40) indicate a mature kerogen in the oil-window zone or post-mature kerogens. Some higher PI values $(>0.40)$ most likely indicate migrating hydrocarbons. However, these high values of PI or TR could be attributed to the predominance of the inertinite content of Type III kerogen and the hydrogen deficient which minimizes the generation potential (S2) of the kerogen during pyrolysis.

The hydrocarbon type index (S2/S3) ranges from 0.52 to 2.36 (average 1.04) in well A5, from 0.13 to 1.27 (average 0.47) in well A3, and from 0.13 to 0.79 (average 0.37) $\mathrm{mg} \mathrm{HC/g}$ rock in well A8 (Figs. 5 \& 6 and Table 1). These values always are less than 2 which denote generation of gaseous hydrocarbons. 


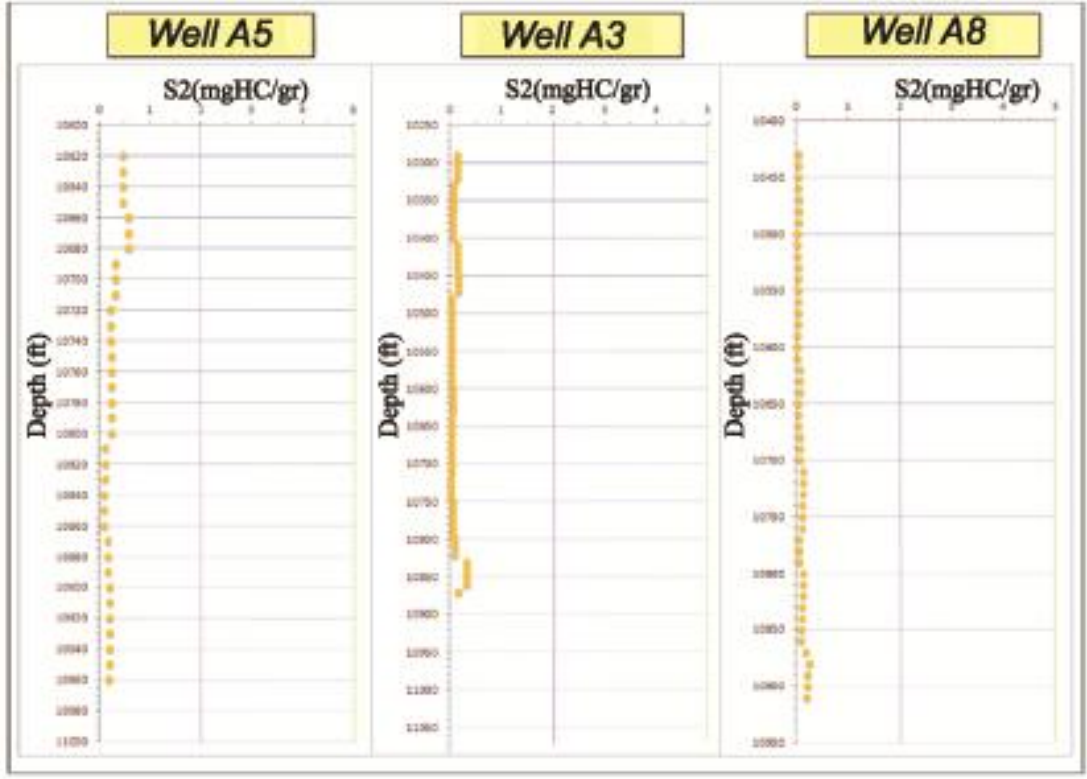

Fig. 9. Plot of S2 (mg HC/g rock) versus depth for Sirte Shale in some Wells, Arshad area, Zaltan Platform, Sirt Basin, Libya.

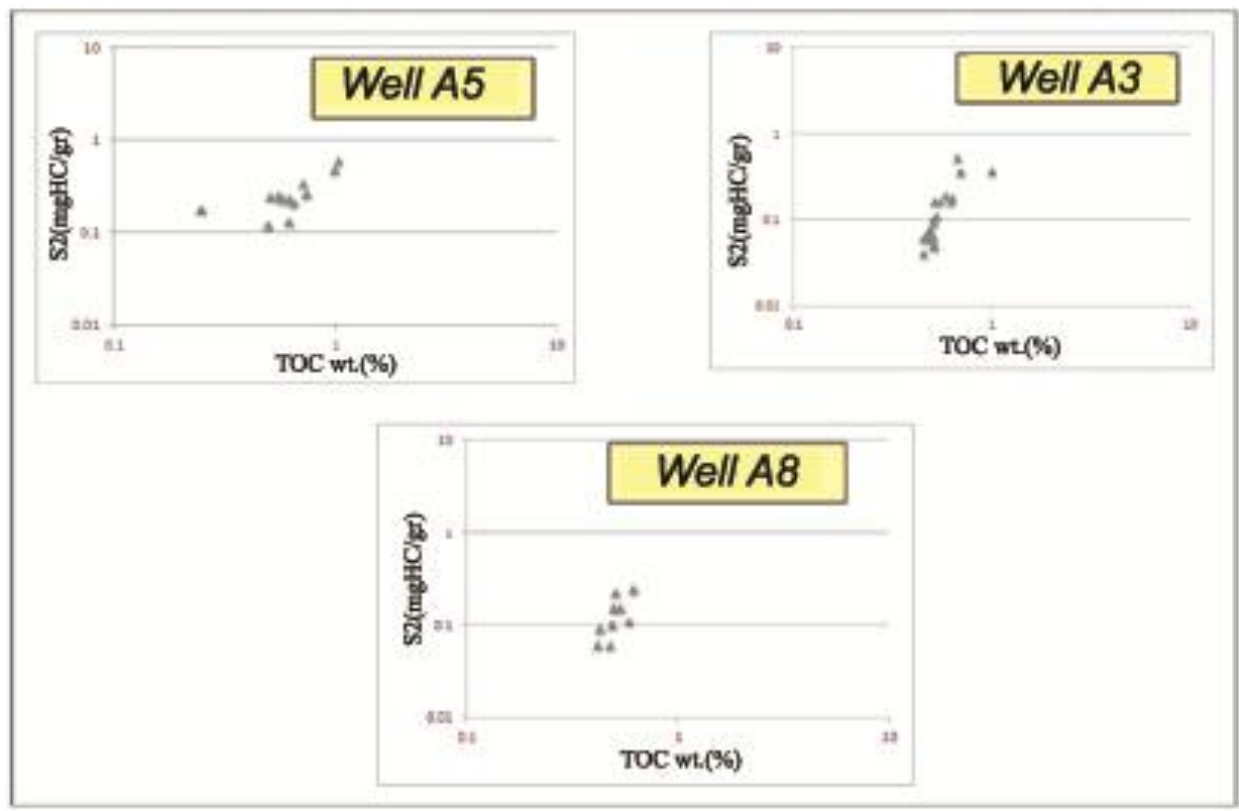

Fig. 10. Plot of TOC (wt. \%) vs. S2 (mg HC/g rock) for Sirte Shale in some wells, Arshad area, Zaltan Platform, Sirt Basin, Libya. 


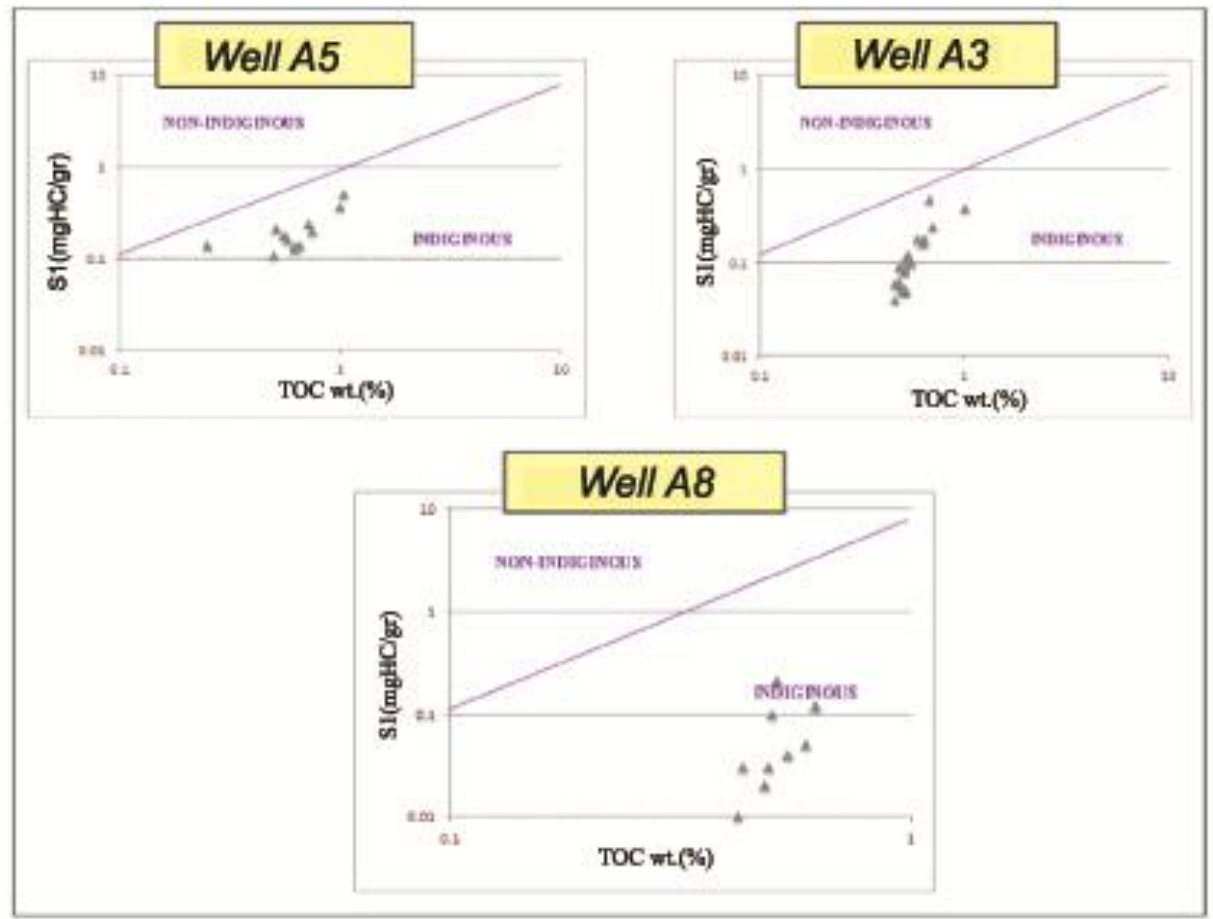

Fig. 11. Plot of TOC (wt. \%) vs. S1 (mg HC/g rock) for Sirte Shale in some wells, Arshad area, Zaltan Platform, Sirt Basin, Libya.

\section{Maturation of organic matter (Kerogen) of Sirte Shale in Arshadrea \\ Thermal Alteration Index (TAI) and VitriniteReflectances (Ro, \%) of kerogen samples:}

The TAI values measured for the AOM of kerogen samples from Sitreshales of wells A5 and A3 range from 5 to 6 indicating late to over maturity levels (Fig. 12). This means that Sirte Shale have been buried in the gas window zone. Also, these TAI values are equivalent to Ro (\%) range 1.3-1.4\% which are determined for Sirte Shale in well A5 at depth interval 10620'-10950'. According to Waples (1985) and Peters (1986) these Ro values denote the late oil window zone (Ro up to $1.35 \%$ ) and gas window zone (Ro > 1.35\%). However, these values go in harmony with the maturity levels given by the modified van Krevelen diagrams of HI and OI values of the analyzed samples of Sirte Shale which indicate over mature plots of all the analyzed samples (Fig. 8).

\section{The hydrogen index (HI) and Tmax:}

The HI values of kerogens of analyzed Sirte Shale samples from wells A5, A3 and A8 which are less than 150 (av. 30) indicate type III kerogen of poor potential in all samples (Fig. 13A-C and Table 2). The Tmax values of the analyzed samples show random relationship with depth. At some relatively shallow depths $\left(10320^{\prime}-10400^{\prime}\right.$ in well A3) it is high $\left(445-446^{\circ} \mathrm{C}\right)$ indicating mature source rocks with Type III kerogen, while at greater depths $\left(10440^{\prime}-11050^{\prime}\right)$ it is less than $405^{\circ} \mathrm{C}\left(337-405^{\circ} \mathrm{C}\right)$ denoting immature source rocks with Type III kerogen too (Fig. 13A). The same case in well A8 where it measures $437-444^{\circ} \mathrm{C}$ at depths $10430^{\prime}-10550^{\prime}$ and $441^{\circ} \mathrm{C}$ at depths $10790^{\prime}-10820^{\prime}$ denoting mature source rocks with Type III kerogen while it is less than $430^{\circ} \mathrm{C}$ at greater depths which means immature source rocks with Type III kerogen too (Fig. 13B). On the other hand, the Tmax of samples in well A5 is less than $430^{\circ} \mathrm{C}$ indicating immature source rocks with Type III kerogen (Fig. 13C). It is worth to mention that all plotted samples prove mature to immature gas-prone type III kerogen.

This contradiction between maturity levels given by results of the TAI and Ro values (mature to over mature levels) and those of the pyrolysis Tmaxvalues (immature to early mature) could be attributed to the problems associated with Tmaxdata. 
Table 2. Geochemical log of the Sirte Shale source rock in well A5, Arshadarea.Zaltan platform, Sirt BasinLibya.

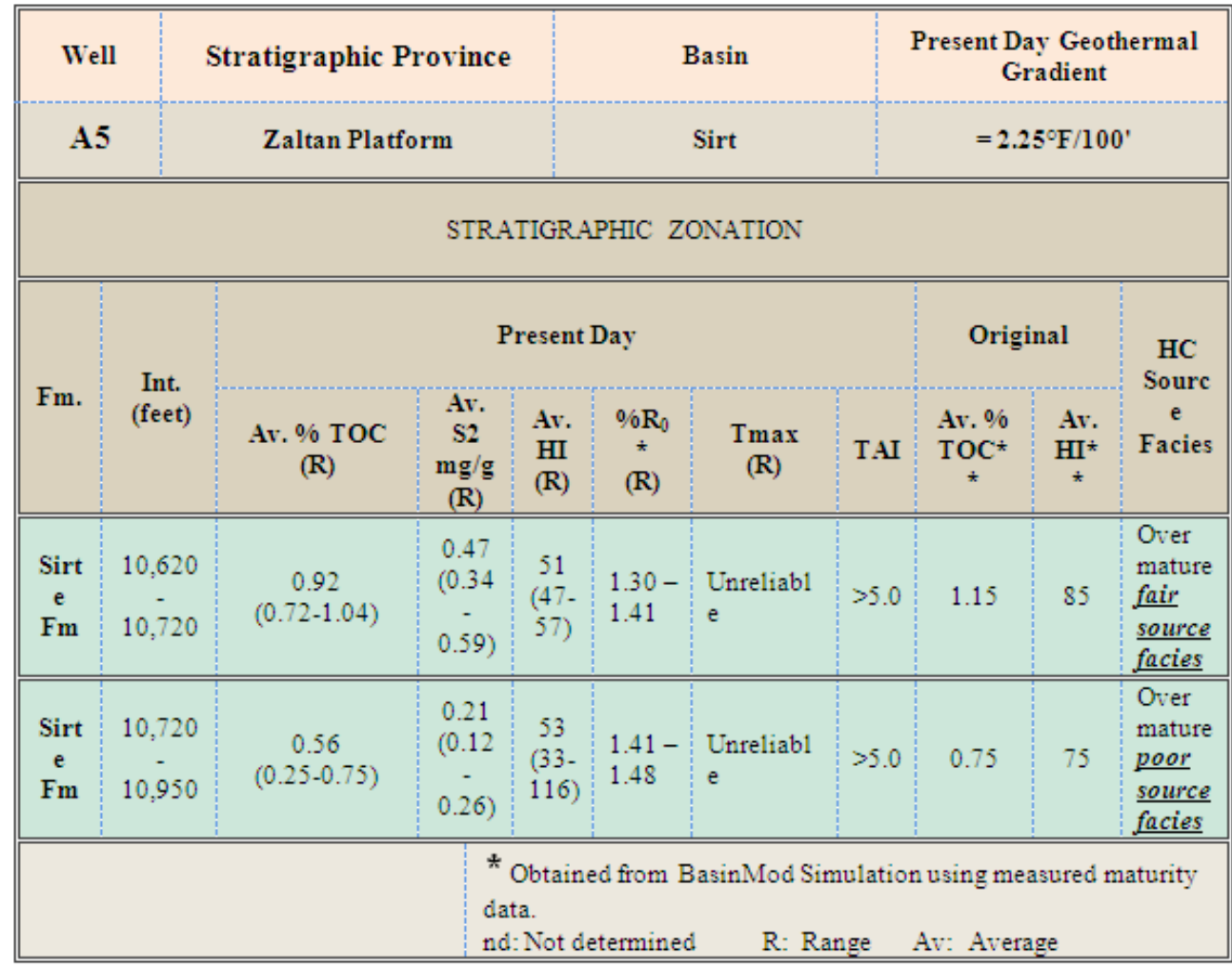

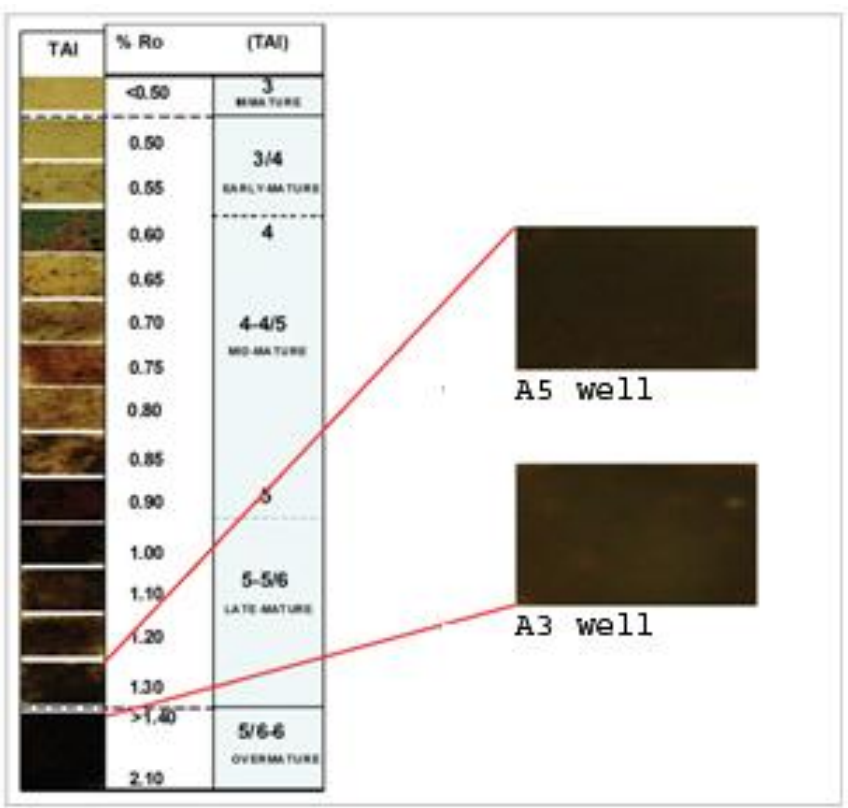

Fig. 12. TAI and its equivalent $\%$ Ro values of the Sirte Fm. in wells A5 and A3 (AOM \%Ro:1.30-1.40) in Arshad area, 

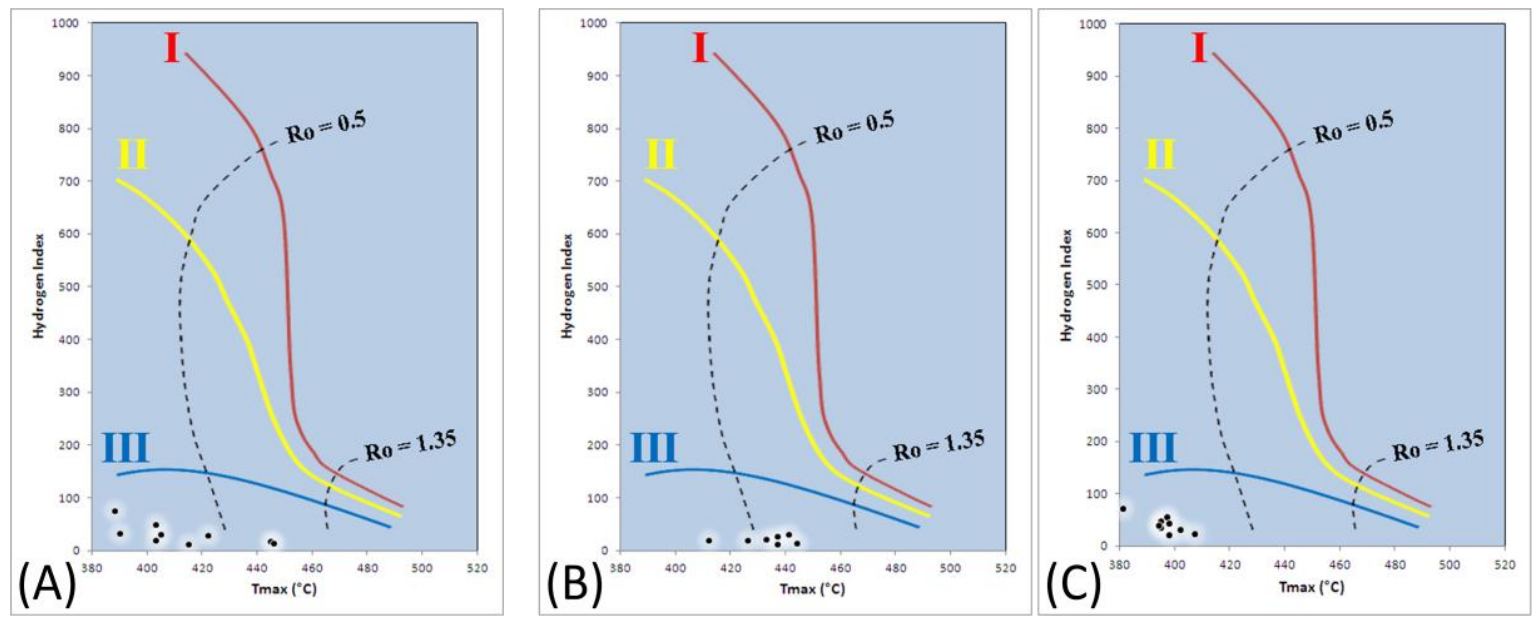

Fig. 13. A plot of HI versus Tmax for the Sirte Shale source rock, wells: A3(A), A8 (B) and A3 (C) of Arshad area.

\section{Thermal Maturity of source rocks in Arshad area}

Methods of modeling of basin maturation have been outlined by many investigators. The most particular among them are Tissot and Wellte (1984), Wapleset al. (1992). In this study the geochemical models suggested by these authors are followed to evaluate the source rock maturity in the area. Accordingly, the oil window, in this work, is defined as an imaginary zone enclosed between $0.8 \mathrm{Ro} \%$ as a top or roof of the zone of peak generation and expulsion and $1.35 \mathrm{Ro} \%$ as the base or floor of the zone. Below this zone begins the gas generation zone.

Two wells (A3 and A5) in the area are modeled for constructing the maturity profiles. No wells have enough vitrinite reflectance measurements hence the geothermal gradient values are used. The Geothermal Gradient used in constructing the thermal models of the studied Arshadarea is taken from the published works.Hallett (2002) pointed out that the geothermal gradients in the Sirt Basin within averages $25.5{ }^{\circ} \mathrm{C}$ $/ \mathrm{km}$.Accordingly, burial history diagrams are constructed for the two wells A5 and A3. Burial history profiles were obtained from Basin Modeling of wells using Platte River ${ }^{\mathrm{TM}}$ associates BMOD software. The kinetic modeling was conducted to determine the hydrocarbon generation and expulsion from the source rocks.

Maturity and Hydrocarbon Generation Modeling:

The thermal burial history curves of wells: A5 and A3 in Arshad area indicate that Sirte Shale had been buried in the early generation (early maturity, Ro: 0.6-0.65\%) since 46 to 50 M.Y. ago (Middle-Late Eocene time) at depth range 5150'-5200' (Fig. 14). The wells had reached the top oil generation zone (Middle maturity, Ro: o.65-0.9\%) since 35-44 M. Y. ago (Late Eocene-Early Oligocene time) at depth range 6500'-6600'. Also, Sirte Shale had been buried in the top peak oil generation or oil window (Late maturity, Ro: 0.9-1.35\%) since 4 to 13.5 M. Y. ago (Middle Miocene-Early Pliocene time) at depth range 9100'-9600'. Accordingly, time of hydrocarbon expulsion has started since 15 M. Y. nearly during the Middle Miocene time (Serravallian age). The top main gas generation (dry gas window, Ro: > 1.35\%) has not been reached by the Sirte Shale in the area, although the equivalent Ro values (1.4\%) and the TAI (5-6) denotes the roof of the gas window zone.

It is worth to mention that, this thermal maturity levels of Sirte Shale given by burial curves (late mature or top oil generation, Ro: $0.9-1.35 \%$ ) are almost in accordance with the maturity levels given by results of the TAI and Ro values (mature to over mature levels, Ro: 1.35-1.4\%).However, since wells: A5 and A3 of Arshad area are located in the Zaltan platform, these results and conclusions could represent the maturity levels of source rocks within the Zaltan platform in relative to the trough areas in Sirt basin. 


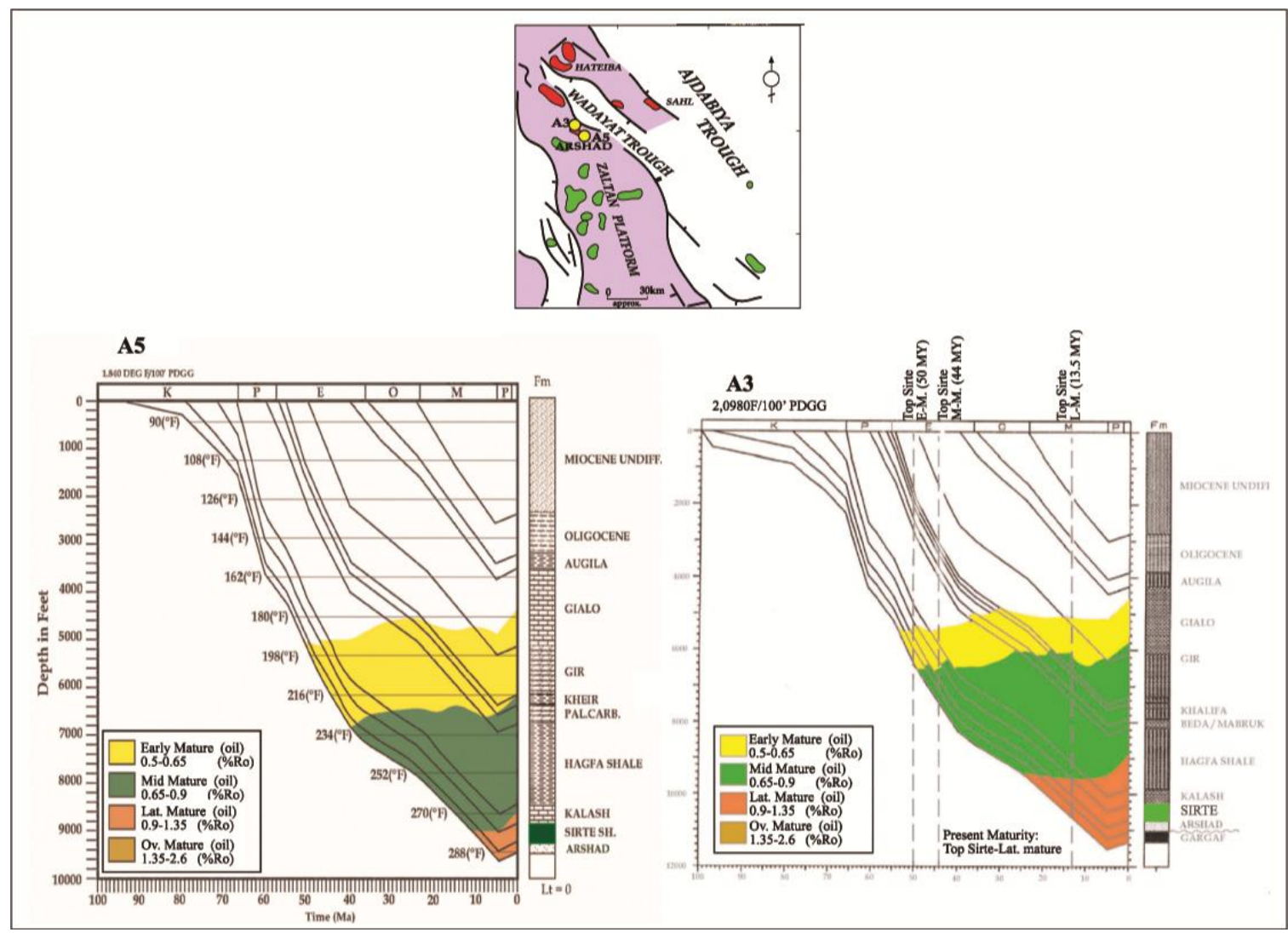

Fig. 14. Burial history curves of wells: A5\&A3, Arshad area, Zaltan Platform.

\section{Hydrocarbon characterization, oil to oil and oil to source rock correlation}

Six oil samples from Arshad area were included in this assessment. The oil samples were recovered from the Upper Cretaceous reservoirs. Two of them are condensate and the remaining are non-waxy normal oils. The samples were analysed by whole oil gas chromatography (Table 6). However, discussion will be addressed on 3 oil samples from wells: A8, A10 and A11.

Table 6.Physical properties of oils from wells A8, A10 and A11, Arshad area, Zaltan platform, Sirt Basin, Libya.

\begin{tabular}{|c|c|c|}
\hline Well Name & API $^{\circ}$ Gravity & $\begin{array}{c}\text { Viscosity } \\
\text { (Centipoise) }\end{array}$ \\
\hline 4M1-6 & $37.0^{\circ}$ & 42.1 \\
\hline 3M1a-6 & $46.2^{\circ}$ & 33.7 \\
\hline 3M10-6 & $47.9^{\circ}$ & 32.5 \\
\hline
\end{tabular}

\section{Oils of A10 and A11 wells}

These oils show a narrow range of physical properties; 46.2 and 47.9 API $^{\circ}$ Gravity is high where as 33.7 and 32.5 centipoise viscosity, respectively (Table 8 ). The whole oil gas chromatograms (Fig. 15a) of these two oils show abundance of volatile hydrocarbons and do not indicate water washing or biodegradation. The later may be occur in shallow reservoir $(<1500-2000 \mathrm{~m})$ at $<70-80{ }^{\circ} \mathrm{C}$ (Bjolykke, 2010). Then the $\mathrm{API}^{\circ}$ Gravity results reveal light oils $\left(>31.1^{\circ} \mathrm{API}\right)$.

The C15+saturate fraction gas chromatograms (Fig. 15b) show steady decrease of long chain hydrocarbons suggesting that these oils are thermally mature. $\mathrm{Pr} / \mathrm{Ph}$ ratio (Pristane/Phytane) (> 1) indicates that these oils were generated from clastic source rocks under oxic conditions (Hunt, 1996). 


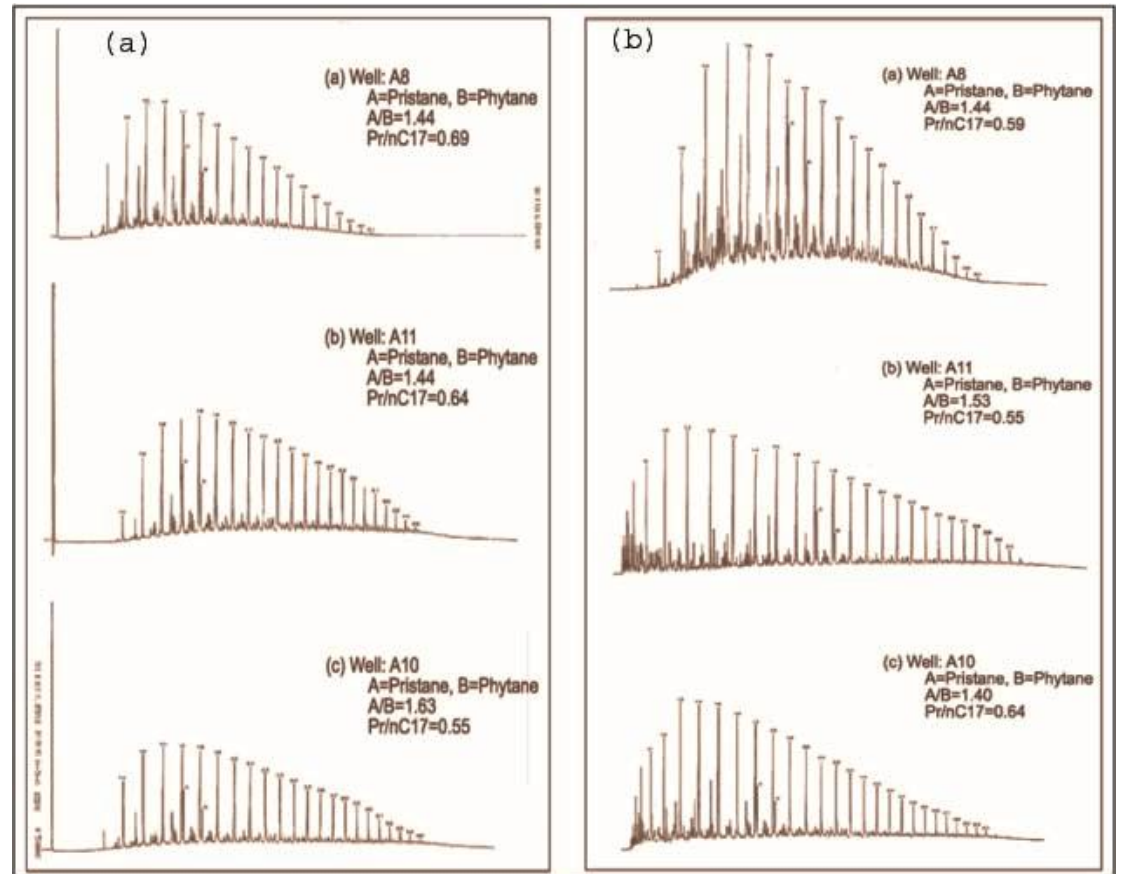

Fig. 15:(a) Whole-sample oil gas chromatograms, (b) C15+ gas chromatograms, wells: A8, A11 and A10, Arshad Fields, Zaltan Platform, Sirt Basin, Libya.

\section{Oil of A8 well}

This oil is heavier than that of the oils recovered from wells: A10 and A11 (Table 6) (37.0 API Gravity and 42.1 Viscosity). The whole oil gas chromatogram shows depletion of light hydrocarbons (Fig. 15a). Although the biodegradation produces heavy oils (low $\mathrm{API}^{\circ}$ gravity) with depleted light hydrocarbons, it is readily identified from the increase of concentration of pristane and phytane (isoprenoids) with respect $\mathrm{nC} 17$ and $\mathrm{nC} 18$ and cyclic naphthene compounds (big hump underneath the normal chain hydrocarbons (Fig. 15b). In this oil, however, $\mathrm{Pr} / \mathrm{nC} 17$ and $\mathrm{Ph} / \mathrm{nC} 18$ are similar to the oils recovered from wells: $\mathrm{A} 10$ and $\mathrm{A} 11$. Therefore, the depletion of light hydrocarbons is mostly due to bad handling and not biodegradation. More work has to be done to determine whether this depletion of light hydrocarbons was from water washing. The general shape of the whole oil and $\mathrm{C} 15+$ gas chromatograms suggest the oil recovered from well A10 was derived from a mature source rock.

\section{Oil-Oil correlation}

The $\mathrm{C} 15+$ gas chromatograms of all the oils analyzed suggest that they are mature. $\mathrm{Pr} / \mathrm{nC} 17$ and $\mathrm{Pr} / \mathrm{Ph}$ ratios reveal that these oils were generated from a similar source facies and that the precursor source rock was marine. The source rock of these oils most likely is the Upper Cretaceous Sirt Shale in Ajdabiya Trough. Further oil-source rock correlation studies are required between Sirt Shale and oil accumulations in the different oil fields in Zaltan Platform.

Also, a little quantity of oil was generated in the Wadayet Trough, in which Sirte Shale source rock passed the oil window and has entered the gas window with its oil- and gas-prone Type II kerogen. Hence, the main generated hydrocarbons expected in this trough are the dry gases. There is no enough amount of hydrocarbons were generated at the Arshad area due to the poor generation potential of Sirte Shale source rock and its high content of type IV kerogen. On the other hand, substantial quantities of oil were generated and expelled from the marine Sirte Shale in the West Flank Ajdabiya Trough since it has reached the oil window with its high content of the oil- and gas-prone type II kerogen.Thus, all the gases in Zaltan Platform, most likely, were derived from Wadayet and West Flank of Ajdabiya Troughs.

On the other hand, Roohi (1996) stated that, structurally it is not possible for oils to migrate to the westward direction from South Hagfa Trough to the Arshad area. Therefore, the Ajdabiya Trough could be the major source of the hydrocarbon accumulations found in the Zaltan platform. In addition, Burwoodet al. (2003) concluded that strata in Ajdabiya Trough plunges steeply to the north driving entire section down into the gas window. This is demonstrated by the presence of gas discoveries at Sahl and Assoumoud Fields (northeast Arshad area) on the northwest flank of the basin. 


\section{Petroleum systems in Sirt Basin (General overview)}

Generally, the age distribution of the prolific petroleum source rock in Sirt Basin indicated that the Cretaceous time (85 M. Y.) referred to the second cycles of distribution and corresponds to the second cycle of sea level changes of present time (Vail, 1978). Also the geological setting during this time was marked by several times of marine transgression events over continental depressions and platforms often favored source rock deposition. Deposition of thick Upper Cretaceous and Tertiary sediments was associated with source rocks in the troughs versus relatively much thinner sediments associated with prolific reservoir rocks in the platforms which provided an excellent environment of hydrocarbon generation and accumulation in the Sirt Basin (Roohi, 1996).

\section{Source rock characteristics of Sirte Shale}

In Sirt Basin, the average TOC of Sirte Shale source rock averagevaries from 2 to 5\%, (occasionally exceed $10 \%$ ) denoting good to excellent potential source rock.

\section{Composition of organic matter and kerogen type in Sirte Shale}

The composition of the organic matter in the source rocks was the subject of many investigations as Roberts (1970); Williams (1972); Clifford (1986); Roohi (1996); Baric et al. (1996) and Sikanderet al. (2006). Hallett (2002),mentioned that the quality of kerogen in the Sirte Shale and the distribution of kerogenfaciesare closely related to the Campanian paleogeography. Type IV kerogen, inert oxidized plant material, is found on the highest areas of the emergent platforms, particularly on the Az Zahra-Al Hufrah, Al Jahamah and Zaltan platforms. This material had prolonged exposure to oxidizing conditions. Kerogen type grades from type III around the trough margins, to type II in the centre of the troughs. Type I kerogen has not been found in the Sirt Shale. This is in accordance with the results of the present study which distinguished Types III and IV in the Sirt Shale source rock in Arshad area within Zaltan Platform.

However, the kerogenfacies distribution pattern modified by Hallett (2002) after El-Alamiet al. (1989) indicates that Sirte Shale source rock in Ajdabiya Trough, and Wadayet Trough within it (to the east of Zaltan Platform), is mainly characterized by oil- and gas-prone Type II kerogen. Hence, Sirte Shale source rock could generate oil and gas in these troughs. Consequently, the accumulated hydrocarbons in the oil fields in Zaltan Platform most likely were sourced from the Sirte Shale mature source rocks in the generative zones within the Ajdabiya and Wadayet troughs to the east.

\section{Thermal maturity of organic matter in Sirte Shale}

Thermal maturity levels of the Sirte Shale have been carried out using spore coloration and vitrinitereflectances of kerogen. Six generation kitchens in which the Sirt Shale has reached, and in some cases passed, optimum maturity zone. Depth to the oil window in most of these areas ranges from 3000 to $3500 \mathrm{~m}$. The six areas are the northern Zallah Trough, Al KotlahGraben, southern Hagfa Trough, southern Ajdabiya, northern Ajdabiya and Hameimat Troughs (Fig. 1). A late mature stage of gas/condensate generation has been reached in both of the Ajdabiyaand Wadayatsource kitchens. Consequently, the Al Kotlah, southern Hagfa and Ajdabiya/Hameimat Troughs represent source kitchens from which large amounts of oil have been generated (Fig. 17). On the other hand, in the platform areas and the northern part of Sirt Basin the Upper Cretaceous source rocks are either immature or lean.

In the Hagfa Trough, adjacent to the ArRaqubah field, modeling studies combining burial history and Lopatin's Time Temperature Index (TTI) have demonstrated that the Sirt Shale entered the early phase of oil generation during the mid-Eocene and reached peak generation during the Oligocene (El Alami, et al., 1989; Hallett, 2002). In the southern Ajdabiya Trough similar studies show that peak oil generation did not occur until the mid-Miocene. Consequently, in Sirt Basin, hydrocarbon generation commenced about 50 million years ago (M. Y.) in the deeper basins, about 40 M. Y. in many other areas, and may continue to the present day (Hallett, 2002).

\section{Migration and entrapment of hydrocarbons in Sirt Basin}

The hydrocarbon generation model consists of deposited source rocks, hydrocarbon generation and its expulsion in the troughs and lateral migration into fault boundaries which are followed by vertical migration along fault fractures and its entrapment in vertically sealed reservoirs within traps in the platforms (Sikanderet. al., 2006). On the other hand, hydrocarbons were generated in the troughs and migrated into the platforms areas later in an appropriate geological setting (Roohi, 1996).

In general, hydrocarbons generated from the Upper Cretaceous shales have migrated into reservoirs of multiple ages dominated along faults to horsts. However, these reservoirs are charged largely by vertically migrating hydrocarbons along horsts block faults from Upper Cretaceous source rocks that occupy structurally low area in the grabens (Ahlbrandt, 2001). 


\section{Petroleum system of Arshad area in Zaltan Platform}

The TOC and Pyrolysis data together with the preservation and thermal maturity data set clearly obtained from selected wells suggest that the Sirte Shale sediments in the Arshad area have no potential for generating hydrocarbons. The interpretation of geochemical data of Sirte Shale sediments for Arshad area indicates that they are poor and unreliable source rocks because of intensive oxidation of the sediments. Also, they have not generated any significant amount of hydrocarbons due to the depth interval deficient of source rocks in the highs and platforms. On the other hand, marine transgression that caused by change of the rate of sea level over platforms may play the role of formationunfavorable environments for planktonic materials in the Arshad area. Hence, the oils and gases no doubt encountered in the Arshad area must have been derived from source rocks located in the troughs around the Zaltan platform in which lies in Arshad area.

Meanwhile, marine Sirte Shale in Arshad area probably was not sufficient thick and/or deeply enough buried on the Zaltan Platform to generate significant hydrocarbons. On the other hand, depositional history of Sirt Basin adequate that marine sedimentary deposits started in the troughs and gradually covered the highs and platform areas. The Sirte Shale in this area presumably remained relatively higher than in the troughs thereby it lacked anoxic conditions to preserve organic matter in the sediments. Therefore, the highs and platforms appear to have lean source rocks with TOC results more or less $0.5 \%$ not capable to generate enough hydrocarbons to saturate the source rocks. Hence, in spite of TOC and Tmax results, Sirte Shale is considered non-source rocks and negligible hydrocarbon source potential. The amount of hydrocarbon generation is so small and their expulsion cannot be occurring.

In east side of the study area in the western Flank of Ajdabiya Trough, similar analysis indicates that the Sirte Shale has good potential for generating good to very good amounts of liquid hydrocarbons with associated gas (av. TOC, $2.85 \%$ \& Tmax above $460^{\circ} \mathrm{C}$ )(Sikander and Basu, 2005; Sikanderet al. 2006). In Deep Wadayet Trough, northeast study area (for example, in certain well results) it is also indicated that the Sirte Shale is generating gas at the present time. The Thermal Alteration Index (5/6- $6 \sim=>1.40 \%$ Ro) and BMOD simulation indicating an over-mature thermal maturity level (Dry gas window). Therefore, all the information mentioned above, it is now generally accepted that the hydrocarbons were generated in the troughs and migrated into platforms. The hydrocarbon comes to Arshad area and around fields in the north Zaltan Platform from the troughs. The marine Sirte Shale sediments in this case provide as cap rock for underlying sandstone reservoirs in the area of study.

In addition, previous studies denoted that the distribution of the Sirte source rock varies throughout the Wadayet and West Flank of Ajdabiya Troughs. The Campanian shale intervals is generally lean along the northwestern embayment, north and west of the Attahaddy structure to north of Arshad area, and thin on the southeast flank of the Attahaddy structure. It becomes thick southeastward in the central and southeastern part of the trough, whereas along the northern margin of Zaltan Platform it is generally thin and poor. The South-North structural cross section from Zaltan Platform to Wadayet Trough shows that Sirte Shale thickness increases toward east and northeast at the depocenter of the Wadayet Trough. Also, it is quite thick in the western flank of AjdabiyaTrough. On the basis of the structural configuration of Sirt Basin and burial depth of maturation for potential source rocks, Roohi (1996) assumed that deep Ajdabiya was the principle site of major hydrocarbon generation for the accumulations found in the Sirt Basin.Migration (expulsion) trend was mainly in WSW of the area between $45^{\circ}-270^{\circ}$ including Zaltan Platform.

It is worth to mention that, the present geochemical model of the Sirte Shale source rock and all the above mentioned geological and geochemical data prove the conclusions suggesting the presence of generative zone (kitchens) in the Ajdabiya and wadayet troughs in which the Campanian Sirte Shale source rock is distinguished as an effective source rock generating oil and gas.

\section{Migration mechanisms and pathways in Zaltan Platform}

Therefore, most of the previous works suggests hydrocarbon lateral and vertical migration from these troughs towards the high area of Zaltan Platform (Keskin and Abugares, 1987;Hallett, 2002). Meanwhile, some authors believed that the oil migrates from Hagfa Trough to the western side of Zaltan platform but remains to be proved. In addition, $\delta \mathrm{C} 13$ of source rocks in Hagfa Trough and West Flank of Ajdabiya Trough are similar to $\delta$ C13 of oils in Zaltan Platform (Sikanderet al., 2006) and also oils in the Arshad area since they are all marine deposits. On the other hand, many petroleum geologists in Libya are not on account of hydrocarbon migration from Hagfa Trough as structurally it is not possible for oil to migrate from Hagfa Trough to Arshad area but it is easy for oil to migrate from the western Flank of Ajdabiya Trough to the Arshad area.

In the present study, based on the geologic setting and geochemical model of Arshad area and Zaltan Platform within Sirt basin, it is concluded that in Arshad area and the adjacent troughs the hydrocarbon migration directions have took place vertically and laterally in the westward up-dip migration direction. Hence, oil has migrated from the Campanian Sirte Shale source rock which has reached the oil-window in western flank of the South Ajdabiya Trough to the Mezozoic and Paleozoic reservoirs in Zaltan Platform and also to 
UpperCretaceous Arshad sandstone reservoir in Arshad oil field as well through juxtaposition structural situation to fill the structural closures of the different fold traps and also the fault-block structural traps in Zaltan Platform (Figs. 16\& 17). Likewise, westward up-dip direction of gas migration has took place from the Campanian Sirt Shale source rock which has been buried in the gas-window in the deep Wadayet to the Mesozoic and Paleozoic reservoirs in Zaltan Platform in North Arshad gas field as well (Figs. 16\& 17). This is in accordance with conclusion ofSikanderet al., (2006).

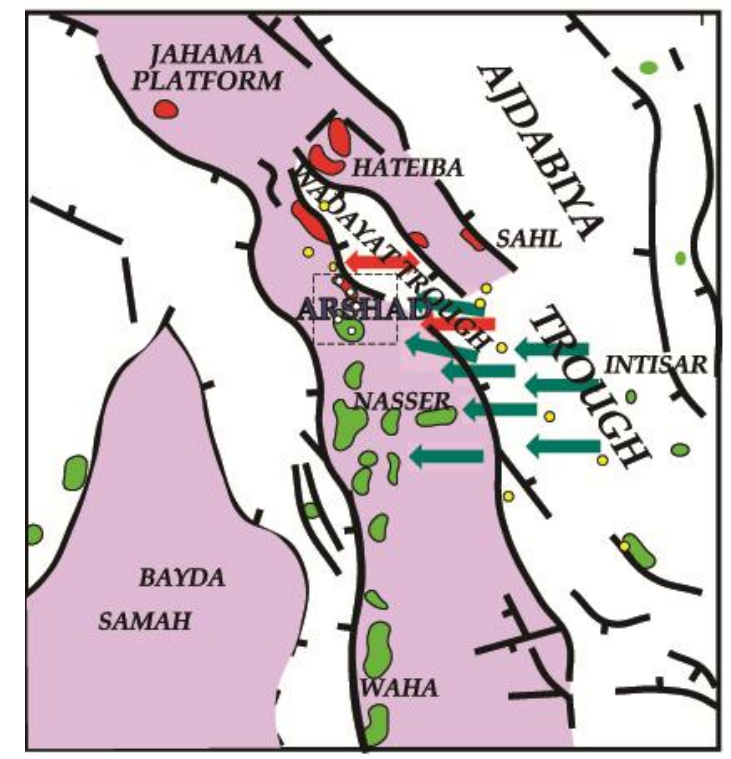

Fig. 16. Hydrocarbon generation kitchens in relation to the principal tectonic elements and migration pathways to the oil and gas accumulations in Zaltan platform and Arshad oil and gas fields in Sirt Basin. (Note the migration directions represented by green, oil; and red, gas, arrows).

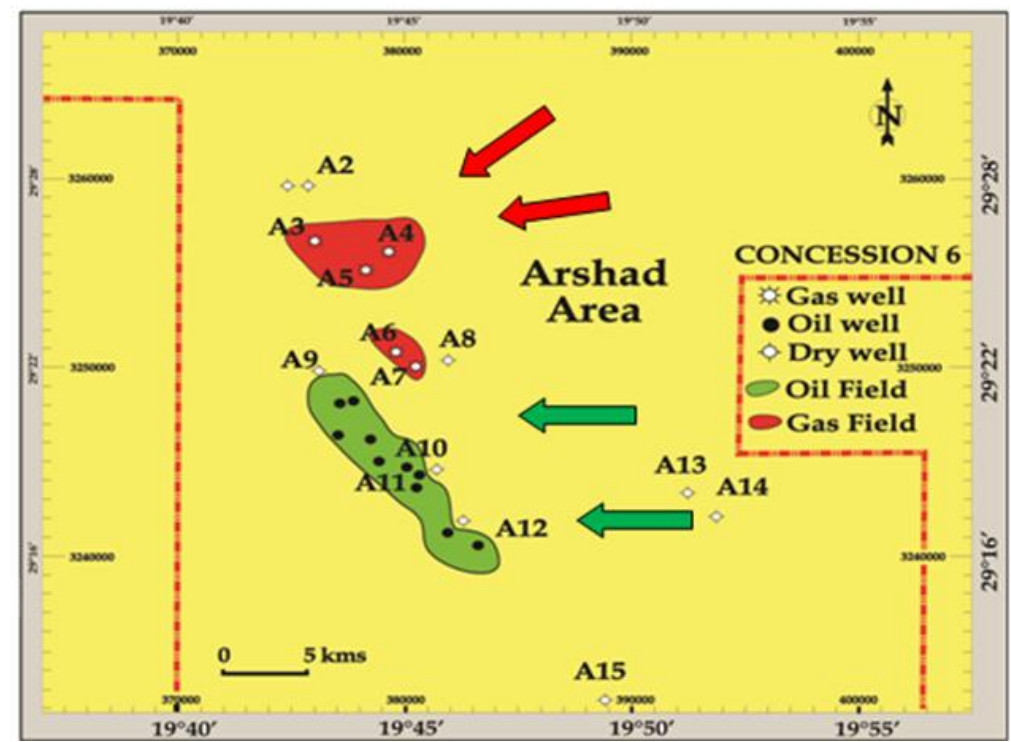

Fig. 17.Location map of the the hydrocarbon productive fields in the study area (Note the migration directions represented by green, oil; and red, gas, arrows).

\section{Petroleum system Events of Arshad area}

Structually, Sirt Basin is differentiated into three phases (Figs. 2 and 4):

1- The Pre-rift phase occurred prior to rifting and block faulting consisting of Palaeozoic rocks.

2- The Syn-rift phase was developed during the Early Cretaceous to Late Eocene. During Late Cretaceous time, shale was deposited in troughs and shallow marine clastics and carbonates were deposited on high areas. The Sirte Shale (Late Cretaceous) forms the effective source rock in most troughs of Sirt Basin. 
3- The Post-rift downwarping phase was characterized by graben fill, basin sag was developed in Post-Eocene to Recent of tectonic phase IV of Baridet al. (1996).

Based on the above review of the tectonic phases, depositional facies, geochemical and reservoir characteristics and oil and gas prospects of the sedimentary section in Arshad area, the petroleum system of Arshad area is considered known one (!) as much as it includes all the requirement elements of the petroleum system. As being stated befor the effective source shales in Arshad structure had been buried since the Middle Eocene time (Early generation) and reached top oil window during Early Oilgocene time. On the other hand, it reached the oil window during the Middle Miocene to Early Pliocene time.

The reservoir rocks of Cambrian-Ordovician Gargaf sandstones and Upper Cretaceous Arshad sandstones are productive rocks with oil $\left(37-47^{\circ} \mathrm{API}\right)$ and/ or gas fields in the area. Consequently, the preservation time and the critical moment have started since 13 M. Y. (Fig. 18).

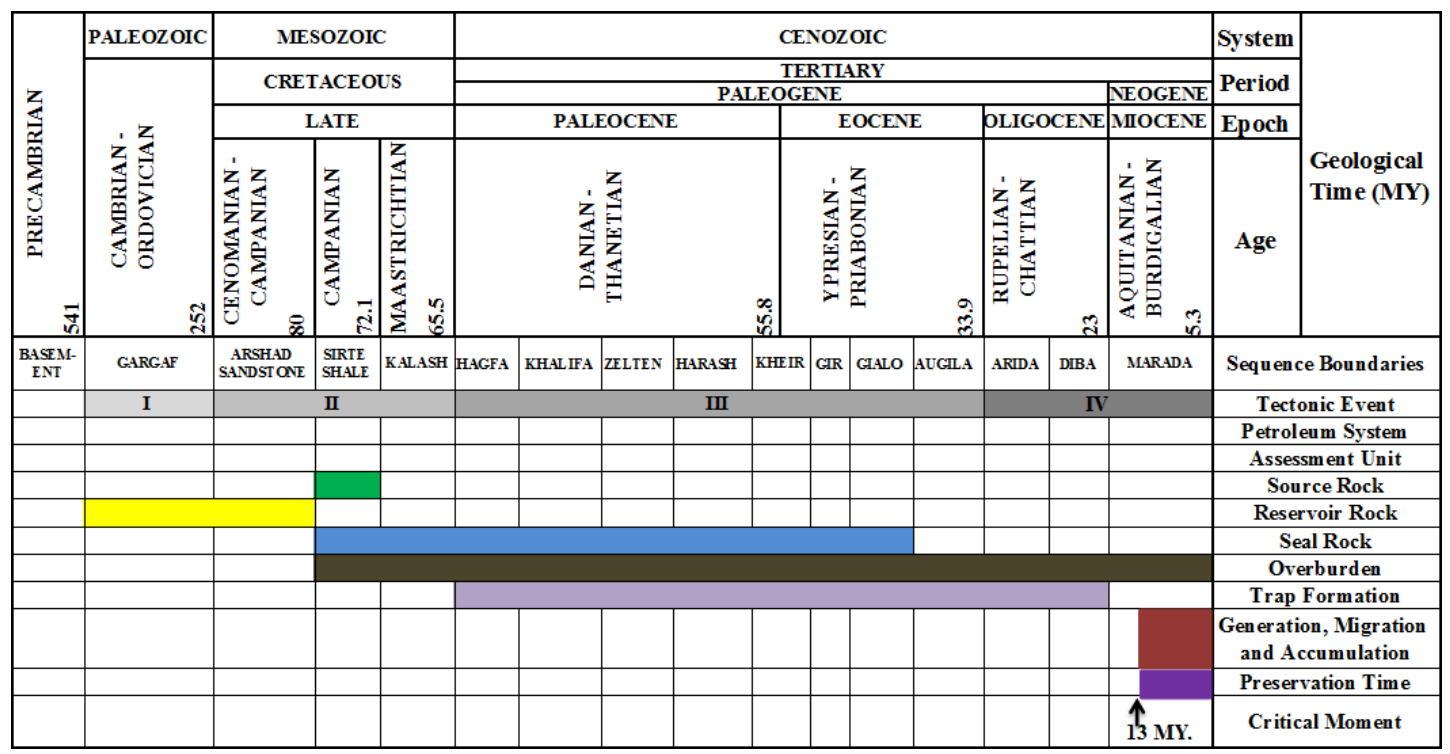

Fig. 18.Petroleum system events of Arshad area, Zaltan Platform, Sirt Basin, Libya.

\section{Conclusions}

Sirte Shale (Campanian) contains enough amount of organic matter (>0.5 wt.\%) to generate and expel hydrocarbons under the suitable thermal maturity level in the area. Their kerogens belong to types III and IV consisting mainly of degraded amorphous organic matter with less amounts of the exinite and woody materials. They belong to the distal oxic shelf marine palynomorphs. The pyrolysis results indicate poor source rock with mature to immature kerogen in the oil-window zone or post-mature kerogens. Sirte Shale have been buried in the top peak oil generation or oil window (Late maturity, Ro: 0.9-1.35\%) since 4 to 13 M. Y. ago (Middle Miocene-early Pliocene time) at depth range 9100'-9600'. Time of hydrocarbon expulsion has started in the area since $13 \mathrm{M}$. Y. nearly during the Serravallian time. The top main gas generation (dry gas window, Ro: > 1.35\%) has not been reached by the Sirte Shale in the area although the equivalent Ro values (1.4\%) and the TAI (5-6) denotes the roof of the gas window zone.

In Arshad area oil has been sourced from Sirte Shale source rock which from western flank of Ajdabiya Trough whereas gas has been sourced from Sirte Shale source rock which has been buried in the gas-window in the deep Wadayet Trough.

\section{Acknowledgement}

The authors would like to thank the authority of Sirt Oil Comapany in Libya for providing the required data upon which this work is based.

\section{References}

[1]. Ahlbrandt, T. S., 2001. The Sirt Basin province of Libya-Sirte-Zeltan total petroleum system. U. S. Geol. Survey Bull., 2202-F, 129.

[2]. Baric, G., Spanic, D. and Maricic, M., 1996. Geochimical characterization of source rocks in NC-157 block (Zaltan Platform), Sirt Basin. In: M. J. Salem, A. S. El-Hawat and A. M. Sbeta (eds.): First Symposium on the Sedimentary Basins, Geol. of the Sirt Basin Elsevier, Amsterdam, II, 541-553.

[3]. Barr, F. T. and Weegar, A. A., 1972. Stratigraphic nomenclature of the Sirt Basin, Libya. Petroleum Exploration Society, Libya, $179 \mathrm{p}$ 
[4]. Barid, D. W., Aburawi, R. M. and Bailey, N. J. L., 1996. Geohistory and petroleum in the central Sirt Basin. In: M. J. Salem, A. S. El-Hawat and A. M. Sbeta (eds.): First Symposium on the Sedimentary Basins, Geol. of the Sirt Basin Elsevier, Amsterdam, III, 356.

[5]. Bjorlykke, K., 2010. Petroleum migration. In: K. Bjolykke (ed.): Petroleum geosciences, from sedimentary environments to rock physics. Springer-Verlag Heidelberg, 349-360.

[6]. Burwood, R. Redfern, J. and Cope, M. J., 2003. Geochemical evaluation of east Sirt Basin (Libya) petroleum systems and oil provenance. In: D. S. MacGregor and N. R. Cameron (eds.): Petroleum geology of Africa; New themes and developing technologies. Geol. Soci., London, 207, 203-240.

[7]. Clifford, A. C., 1986. African oil-past, present and future. In: M. T. Halbouty (ed.): Future petroleum provinces of the world. AAPG, Mem. 40, 339-372.

[8]. El-Alami, M. A., Rahouma, S. and Butt, A. A., 1989. Hydrocarbon habitat in the Sirt basin, northern Libya. Petrol. Reser. J., 1, 1728.

[9]. Hallett, D. and El Ghoul, A., 1996. Oil and gas potential of the deep trough areas in the Sirt Basin, Libya. In: M. J. Salem, A. S. ELHawat and A. M. Sbeta (eds.): The Geology of the Sirt Basin. Elsevier, Amsterdam, II, 455-483.

[10]. Hallett, D., 2002. Petroleum Geology of Libya. Elsevier Science B.V., Amsterdam, 503 p.

[11]. Hunt, J. M., 1996. Petroleum Geochemistry and geology. $2^{\text {nd }}$ ed., W.H. Freeman and Company, New York, 743 p.

[12]. Peters, K. E., 1986. Guidelines for evaluating petroleum source rock using programmed. pyrolysis. AAPG Bull., 70, 318-329.

[13]. Roberts, J. M., 1970. Amal field, Libya. In: M. T. Halbouty (ed.): Geology of giant petroleum fields. AAPG, Mem. 14, $438-448$.

[14]. Roohi, M., 1996. A geological view of source reservoir relationships in the western Sirt Basin. In: M. J. Salem, A. S. EL-Hawat and A. M. Sbeta (eds.): The Geology of the Sirt Basin. Elsevier, Amsterdam, II, 323-336.

[15]. Sikander, H. and Basu, S. 2005. Source maturation, structural synthesis and volumetric estimates for Ajdabiya-Maragh Troughs and Amal-Nafoorah high, Eastern Sirt Basin, Libya. Geol. Report No. 305 (Unpublished), 164 p.

[16]. Sikander, H. and Basu, S., Ertug, K. and Wafa, F., 2006. Atlas of petroleum geology and geochemistry of source rocks and hydrocarbons in Sirt Basin, Libya, SOC's Internal Report.

[17]. Tissot, B. P. and Welte, D. H., 1984. Petroleum Formation and occurrence. $2^{\text {nd }}$ ed., Heidelberg: Springer-Verlag, 699 p.

[18]. Vail, P. R., 1978. Seismic stratigraphy interpretation using sequence stratigraphy Part 1. In: A. W. Bally (ed.): Seismic stratigraphy interpretation procedure Atlas of seismic stratigraphy, 1. AAPG. 27, 1-10.

[19]. Van Krevelen, D. W., 1961. Coal. Elsevier, New York, 514 p.

[20]. Waples, D. W., 1985. Geochemistry in petroleum exploration. International Human Resources and Development Corporation, Boston, $226 \mathrm{p}$.

[21]. Waples, D. W., Kamata, H., and Suizu, M., 1992. The art of maturity modelling, part 1: Finding a satisfactory geologic model. AAPG Bull., 76 (1), 47-66.

[22]. Williams, J. J., 1972. Augila Field, Libya: depositional environment and diagenesis of Sedimentary reservoir and description of igneous reservoir. In: Stratigraphic Oil and Gas Fields-Classification, Exploration Methods, and Case Histories. AAPG, Mem. 16, $10,623-632$. 